City University of New York (CUNY)

CUNY Academic Works

Publications and Research

John Jay College of Criminal Justice

2013

\title{
Alchemy and Inquiry: Reflections on an Inside-Out Research Roundtable
}

\author{
Sarah Allred \\ Berry College \\ Angela Bryant \\ Ohio State University \\ Simone Weil Davis \\ Kurt Fowler \\ Rutgers University \\ Phil Goodman \\ University of Toronto
}

See next page for additional authors

\section{How does access to this work benefit you? Let us know!}

More information about this work at: https://academicworks.cuny.edu/jj_pubs/120

Discover additional works at: https://academicworks.cuny.edu

This work is made publicly available by the City University of New York (CUNY).

Contact: AcademicWorks@cuny.edu 


\section{Authors}

Sarah Allred, Angela Bryant, Simone Weil Davis, Kurt Fowler, Phil Goodman, Jim Nolan, Lori Pompa,

Barbara Sherr Roswell, and Daniel L. Stageman 
CHAPTER 21

\title{
Alchemy and Inquiry: Reflections on an Inside-Out Research Roundtable
}

\author{
Sarah Allred, Angela Bryant, Simone Weil Davis, Kurt \\ Fowler, Phil Goodman, Jim Nolan, Lori Pompa, Barbara \\ Sherr Roswell, and Dan Stageman
}

In 2008, The Inside-Out Prison Exchange Program convened a Research Committee to (1) facilitate a collective, critical, and professional consciousness about social justice, crime, and incarceration through the exploration of the Inside-Out program pedagogy, impact, and effectiveness; (2) develop and encourage proposals for various types of research that focus on The Inside-Out Prison Exchange Program; and (3) establish ethical guidelines for inquiry that would meet and exceed the federal human subjects guidelines in research practices. In fall 2012, Research Committee members Sarah Allred, Angela Bryant, Phil Goodman, Kurt Fowler, Jim Nolan, Lori Pompa, and Dan Stageman joined with Simone Davis and Barbara Roswell for a roundtable discussion of the central claim that Inside-Out is "transformative." This chapter frames and summarizes that conversation. ${ }^{1}$

$\mathrm{T}$

The pressure to research and evaluate successful programs is certainly not news to faculty and professionals responsible for community-based learning, prison education, or - in the case of Inside-Out - the nexus between the two. Diverse stakeholders are interested in better understanding program impacts, from funders and administrators who want to know about the effects of their financial and institutional investments, to staff who may use program evaluation to improve training or curriculum, to faculty and campus professionals who want to understand and improve community-engagement practices and pedagogies. Others see campus-community partnerships as fertile ground to advance knowledge in a range of disciplines (and perhaps to add to their own publication records as well), and view community-engaged work not as the focus of but as a site or context for research. 
Just as the prison context offers a particularly intense instantiation of community-based learning, it also heightens concerns about research in community settings. Research without consent has a long and deeply troubling history in the prison context, and people who are incarcerated have realistic concerns about being treated as objects for research that may be exploitative, harmful, or invalid. Phil Goodman points out that this issue has deep roots "in the rise of 'criminology' as a 'scientific' discipline and a particular modernist/contemporary power-knowledge project to know the 'offender'.... While we can say that research on Inside-Out can and should be less horrific than past research, left unanswered are questions about the ways in which all research in this area is necessarily implicated in the larger project of punishment."

These concerns resonate with those of community-engagement scholars, who, similarly concerned about exploitation and reinforcing power differentials, ask, "Where's the community in community-based teaching and research?" As a result, the Inside-Out research community has been occupied with a series of fundamental questions: Who conducts the research? What or whom is being studied? What questions should be asked? What qualifies as success? What tools and methods should be used? How can we assess claims of transformation? What kinds of inquiry does Inside-Out make uniquely possible?

A felt sense of transformation-a deep knowing that community-engaged work makes a difference-will be familiar to readers who teach in prisons or bring campus and community together. It is what we know when we read a grateful email from an alumna expressing thanks for the experience that gave her purpose and shaped her career, when an incarcerated student recounts an animated phone conversation with his son about the essays they are each writing, when a group of previously disengaged students join together with their neighbors to campaign for social justice in their community. Equally familiar, likely, is the hankering to explain and prove-and the wish to look beyond the class, beyond the semester, and to engage with scope and reach. For this we need longitudinal studies, and yet these require both care and innovation: both ethical and methodological challenges arise when people are leaving prison. As Phil Goodman and Sarah Allred concluded during our roundtable, the traditional scientific model with a contained, tightly defined, and operationalized unit of analysis may not be the most useful here.

Plus, as Angela Bryant notes, the question of "who sets the agenda" cannot be divorced from the paradigms and larger social analyses that a research agenda upholds. Researchers only seek answers to the questions they know to ask. Content analysis of reflection papers, for example, can help focus attention on themes and questions salient for campus and community participants. Even more critically, Participant Action Research (PAR, see chapter 23) is key to inviting the participants themselves to be involved not only in naming the questions but also, as Turnbull et al. show, in conducting inquiry and developing participant leadership. Inside-Out joins a wider effort to challenge the assumptions of the research and practitioner community, to empower community participants as researchers, and to "push the envelope of what is considered mainstream research." This challenge can itself be an impetus for social change.

This is especially true today, when evaluation of both educational and criminal justice outcomes typically focuses on individual-rather than group or 
institutional-transformation, thereby obscuring broad-scale challenges to social systems and institutions. In the case of penal research (and assessment of a program like Inside-Out), this almost always involves a demand for recidivism rates. Just as "retention" or "graduation rates" are at best "partial indicators of student success" that "work around the edges of students' actual learning" - necessary but scarcely sufficient, as Carol Schneider writes, recidivism is a similarly distorting and reductive measure of "success" or impact, not only unable to account for the impact of education on those still incarcerated, but also unable to address impact on family, self-esteem, employment, future education, or a whole range of other reasons for education, from the development of critical thinking to civic participation. ${ }^{2}$ Recidivism is additionally problematic as a purported measure of individual success or failure because of the ways it disregards the systemic flaws that can return people to prison over very minor parole violations.

The motivations for inquiry - and the shapes that inquiry may take-run much deeper, of course, than the documentation of narrowly defined outcomes for external audiences. This volume, in fact, is filled with a kind of wonder. Multiple authors included in these pages use the phrase, "There is something about Inside-Out that..." as they seek to define that something that encouraged risk, deepened engagement with complex texts, disrupted the stereotypical thinking, or enticed people disaffected with school to embrace learning. Each chapter, in its own way, seeks to explain Inside-Out's transformative power, to describe the "crucible" for learning, or the "alchemy" of the Inside-Out model.

While these metaphors of alchemy at first seem to romanticize and mystify the "magic" of Inside-Out, they are actually very telling in the ways that each calls attention not to one method or strategy, but to the program's unique, intense, and carefully sequenced and calibrated mixture and juxtaposition of strategies that makes the whole larger than the sum of its parts. Ella Turenne, for example, invokes Harro's "cycle of transformation," Paul Perry employs Khuri's analysis of the role of emotion in intercultural dialogue, M. Kay Harris draws on Bain's construct of a natural critical learning environment. One approach to Inside-Out research, then, is to ask, "What theoretical frameworks can account for this interpenetration of high impact practices as the source of the transformational power of Inside Out?" Given the explanatory power of these models, how might researchers test a hypothesis about how Inside-Out creates transformative learning? How, in turn, might research into Inside-Out as praxis inform and contribute to our theoretical understanding of civic engagement in higher education?

Perhaps most impressive, of the ten well-documented "high impact" practices identified by George Kuh for the Liberal Education and America's Promise (LEAP) initiative-with the modest goal that every student participate in two of these during his or college career-each single Inside-Out course integrates the key features of seven:

- First-Year Seminars

- Learning Communities

- Writing-Intensive Courses

- Collaborative Assignments and Projects 
- Diversity/Global Learning

- Community-Based Learning

- Capstone Projects. ${ }^{3}$

In his extensive study of the conditions that enable adults returning to school to thrive, Mike Rose similarly identifies an interlocking set of best practices that align with Inside-Out's combination of key elements: a welcoming space, a meaningful context for learning, a small community of learners engaged in a shared enterprise, opportunities to develop "soft skills" and higher order thinking, and, perhaps most significant, metacognitive language and attention to learning itself, with multiple and scaffolded opportunities for students to reflect on their own journey and the process, not just the products, of learning.

Where LEAP identifies large curricular and institutional structures, in his study of "What the Best College Teachers Do," Ken Bain seeks out the ingredients of individual teachers' practice that lead to transformative, or deep learning, what he terms "sustained, substantial, positive influence on how students think, act and feel" (5). He highlights teachers' understanding of teaching as creating conditions for learning, the connection between personal and intellectual development, collaborative work with other students that requires higher order thinking about significant questions, and asking students to make a commitment to the class and the learning. Perhaps most critical to these qualities is the key skill emphasized in Inside-Out's Training Institute, the instructor's ability to "do intellectually, physically or emotionally what they expect from the students" (112).

Even more obvious as an extensively studied explanatory model is Jack Mezirow's ten-stage description of transformative learning. On the basis of a meta-analysis of the empirical literature, Edward Taylor suggests that fostering transformative learning involves the integration of a set of interdependent core elements that, like the Inside-Out approach, include activation of individual experience, critical reflection, dialogue, creation of shared norms, a holistic orientation toward teaching (including affective and relational ways of knowing), awareness of context, and authentic relationships, all made possible through learner-centered teaching.

Beyond the educational literature, one can find explanations of Inside-Out's unique contribution in its emphasis on helping students simultaneously to build what Robert Putnam identifies in Bowling Alone as "bonding capital" (often deep connections among homogeneous groups) and "bridging capital" (the ability to work with diverse others). As Amy Gutmann concludes, "The more economically, ethnically and religiously heterogeneous the membership of an association is, the greater its capacity to cultivate the kind of public discourse and deliberation that is conducive to democratic citizenship" (25). The Inside-Out classroom creates the conditions where students develop the types of close bonds of trust and affiliation typical of "bonding capital" while bridging divides and working with diverse others. Gurin and her colleagues' distinctions among "structural" (demographic), "classroom" (reading, discussion, theory) and "interactional" (peer and informal relationship) forms of diversity offer a related and also well-researched framework; Inside-Out can be understood to maximize the educational value of diversity by activating and connecting these three dimensions of diversity that in most educational settings are distinct or absent. 
Over the years, research into Inside-Out, like other forms of community-based learning, has used frameworks like these to test the claim that the program contributes to change in individuals' attitudes, beliefs, self-perception, etc. Using Likert scale items (Strongly Agree, Agree, Disagree, Strongly Disagree), the Research Committee has considered such pre- and posttest questions as:

- One individual can make a difference in changing society

- I can only learn from an expert or authority

- The criminal justice system treats people of all races equally

- Punishment is the best way to deter crime

- I believe that I have the ability to successfully complete a college degree.

As chapters 22 and 23 elaborate, an approach like this will be of most value only if it is embedded in other forms of inquiry and if it is enriched through the contributions of a networked research community: students, alumni, and think tanks participate in projects and conduct inquiry; crossinstitutional multisite content analysis projects yield themes to be investigated further; and instructors who are interested in different questions, models, and approaches share with and inform each other, creating a collaborative research community.

It was members of that research community who participated in this roundtable discussion. So we put the query to them:

\section{What Sorts of Questions Do You Want to Ask?}

Dan Stageman (DS): I would ask someone who had completed a class, "How has this transformation manifested in your interactions with a community, with your desire to stay involved, with how you act?" If this has long-term effects, people need to be acting on the transformation in other contexts and over the long term.

Lori Pompa (LP): In the original Inside-Out curriculum, the first part of our final reflection paper asks about process-it elicits observations about group process, dynamics. We could add, "Where will you take this from here? What will you do with this?"

Angela Bryant (AB): But at that stage (the end of a semester), they may not know what they will do.

$L P$ : Over the years, I've often gotten letters from alumni, who say things like, "I'm a lawyer and what I'm doing was influenced by Inside-Out..."

Simone Davis $(S D)$ : So would that require a longitudinal study, and what are the ramifications there

Sarah Allred (SA): We definitely need a way to broaden the net.

Jim Nolan $(J N)$ : I think that we all shy away from focusing on individuals in prison as objects as study, in part because it is worrisome whether they can truly give consent. So focusing on context is a good way of proceeding. I ask, to what extent does the classroom change? I want to know whether someone is waiting for the teacher's direction or is involved in and sharing responsibility for a group project—in my classes, typically, a class-created "white paper" that 
goes to the commissioner in the state office. I want to know: Do students take changes in perception back into their respective communities?

$A B$ : How has this work changed our own communities, our learning, and our knowledge production? Roswell and Bryant went on to voice an interest in the program's impacts on participating instructors. How has participation in Inside-Out changed instructors' teaching, research, self-concept, or civic engagement? For example, what do instructors learn as a result of working in correctional settings and confronting institutional barriers? Interviews, syllabi, statements of teaching philosophy would all serve as data sources for this inquiry.

In class, students often shake instructors free from preconceived ideas about the pedagogy's purported benefits. Thereby, students point the way toward different evaluative yardsticks. Here are three examples from our conversation.

1) $S A$ : The transformation that I have observed and been able to share in does not seem to be a unilateral experience. It does not necessarily center on the group project. As we've discussed, moments of unanticipated conflict or disruption may be transformational. And it's hard to plan for this in advance. I once took a class on a tour, and had a horrible experience with the staff member who led it. So the learning does not unfold uniformly. We need a way to respond to something when it happens, to learn how it is labeled.

2) $J N$ : When I started doing Inside-Out, what I observed was that the inside students internalized their role as "criminals." During Inside-Out training we were given warnings against labeling language, but during class, it became a kind of joke, because the inside students used the word "convicts" to describe themselves. The prison is full of language about "choice" and "making the right choices" and inside students use this terminology a lot. The outside students in the class were enrolled in a sociology program, and they put much more emphasis on context, on places — college and prison-where habits and dispositions are re-formed. In this difference, we found a jumping-off point for learning.

3) $A B$ : We talk about group projects as something that brings people together. What we learned from talking with students was that this blurring of lines was not what they say they found most monumental in their thinking. They weren't completely transformed - they went back and forth and revisited old roles and identities and divisions. As an instructor and researcher, I was trying to quash these divisions, but when given an opportunity to contribute, participants corrected me.

We talked about scope. What's our frame-a single class or a community that persists? Inside-Out exists both in its form as a single semester experience and as an opportunity for ongoing programmatic involvement. And we talked about the consequences of the various tools deployed in this research.

$L P$ : Inside-Out classes are delimited by nature, less than 15 weeks long. What impact does that have, compared to, say, a Think Tank that is ongoing? 
$S D$ : What does its boundedness make possible or curtail?

$L P$ : At closing ceremonies, so moving and significant, there is quite a bit of mourning that happens, but it is mourning for more than just the relationships; it's for the loss of the liberating space itself. What is made possible by the knowledge that this has an end? How might this "boundedness" heighten transformation or the perception of transformation?

$J N$ : It hurries it along and makes it more intense.

$A B$ : I'd like to know, for how many people does the experience really end? In Ohio [and across the network], more and more alumni are staying involved in one-credit reading groups, Think Tanks, and independent studies. So when we are measuring the impact of the classroom, we need to do longitudinal work. How do we ask, "What happens when the work doesn't end?"

$S D$ : Certain kinds of transformation require as a foundation the trust that can only be built through sustained relationships. We see this in the ongoing work of think tanks, et cetera, as Angela suggests.

$J N$ : I'm wondering if conceptualizing the entire structure of Inside-Out as a grassroots community would be a more productive avenue of research [which suggests a very different set of frameworks and tools (see Grant and Holley)].

$D S$ : If I were to look at one researcher and one model, it would be Michelle Fine who eschews more restrictive ideas of units of analysis and looks at circuits, like the "Changing Minds" work with Bedford Hills or her more recent work.

$S D$ : This leads back to questions about method, voice, story.

Kurt Fowler $(K F)$ : This makes me wish for something like "Story Corps"idiosyncratic, contextualized. We need a repository of stories and a way to explore what this means in terms of method and moving forward.

$S D$ : People working in the Inside-Out community have expressed the wish for an anthology, an archive of narrative and qualitative research. For me, what's relevant about process in this regard is that stories aren't just the content of the stories themselves. When research projects are collaboratively designed and implemented in a participatory way, shared stories can become active engagements, connective tissue, and crucial context, performances in the Austinian sense. ${ }^{4}$ Telling and listening to a story can be a way of healing and building community. Jim asks, "What is happening in the room, what do you want to have happen?" This is an invitation for the participant to think about agency. It's an invitation to create a story about your own role in community.

\section{Notes}

1. The full text of the roundtable is available at www.insideoutcenter.org.

2. Just as Carol Schneider, the President of the Association of American Colleges and Universities, calls on higher education to better align metrics with what we know about deep integrative learning and what makes it possible, Vernor Munoz Special Rapporteur to the United Nations suggests that human dignity should be a fundamental concern of models and measures of education in detention, not simply "a utilitarian add-on should resources allow it." 
3. George D. Kuh, High-Impact Educational Practices: What They Are, Who Has Access to Them, and Why They Matter (Washington, DC: Association of American Colleges and Universities, 2008). Internships, student research, and study abroad are also identified as high-impact practices.

4. J. L. Austin described some speech acts as far more than descriptive or analytic: they are a kind of doing or making. When we say "Happy Birthday!" our words are themselves a (verbal) action. See J. L. Austin, How to Do Things with Words (Oxford: Clarendon Press, 1962).

\section{References}

Austin, J. L. How to Do Things with Words. Oxford: Clarendon Press, 1962.

Bain, Ken. What the Best College Teachers Do. Cambridge, MA: Harvard University Press, 2004.

Fine, Michelle and Jessica Ruglis. "Circuits and Consequences of Dispossession: The Racialized Realignment of the Public Sphere for U.S. Youth," Transforming Anthropology 17, no. 1 (2009): 120-133.

Grant, Heather. Transformer: How to Build a Network to Change a System: A Case Study of the RE_AMP Energy Network. Monitor Institute, 2010. www.monitorinstitute.com/reamp/.

Gurin, Patricia, Eric L. Dey, Sylvia Hurtado, and Gerald Gurin. "Diversity and Higher Education: Theory and impact on educational outcomes," Harvard Educational Review 72, no. 3 (2002): 330-366.

Gurin, Patricia, Gerald Gurin, Eric L. Dey, and Sylvia Hurtado. "The Educational Value of Diversity." In Defending Diversity: Affirmative Action at the University of Michigan, edited by Patricia Gurin, Jeffrey S. Lehman, and Earl Lewis. Ann Arbor: University of Michigan Press, 2004, 97-188.

Gutmann, Amy. "An Introductory Essay," Freedom of Association. Princeton, NJ: Princeton University Press. 1-27.

Harro, Bobbi "The Cycle of Liberation." In Readings for Diversity and Social Justice, edited by Maurianne Adams, Warren Blumenfeld, Carmelita Casteneda, 50-60. New York: Routledge, 2000.

Holley, June. Network Weavers Handbook: A Guide to Transformational Networks. Athens, OH: Network Weaver Publishing, 2012.

Khuri, Lydia "Working with Emotion in Educational Intergroup Dialogue." Journal of Intercultural Relations 28 (2004): 595-612.

Kuh, George L. High-Impact Educational Practices: What They Are, Who Has Access to Them, and Why They Matter. Washington, DC: Association of American Colleges and Universities, 2008.

Mezirow, Jack. Transformative Dimensions of Adult Learning. San Francisco: Jossey-Bass, 1991.

. "Transformative Learning: Theory to Practice," New Directions for Adult and Continuing Education 74 (Summer 1997): 5-12.

Muñoz, Vernor. "The Right To To Education of Persons In Detention.” Report of the Special Rapporteur on the Right to Education, United Nations Human Rights Council, 2009.

Rose, Mike. Back to School: Why Everyone Deserves a Second Chance at Education. New York: New Press, 2012.

Schneider, Carol Geary. "Losing Our Way: On the Meanings of Student Success," Liberal Education 99, no. 2 (Spring 2013), http://www.aacu.org/liberaleducation/le-sp13/schneider.cfm. 
Taylor, Edward. "Fostering Transformative Learning." In Transformative Learning in Practice: Insights from Community, Workplace, and Higher Education, edited by Jack Mezirow and Edward Taylor, 3-17. San Francisco: Jossey Bass.

Turnbull, Ann P., Jean Ann Summers, Betsey Santelli, Ursula Markey. "Truths Converging: Empirical Support for Intuitive Understanding," NHSA Dialog 5, no. 2 and 3 (2002): 386389. http://www.beachcenter.org/research/FullArticles/PDF/PAR8_TruthsConverging.pdf. 